\title{
A New Late-ripening Large-nut Indigenous Korean Chestnut Cultivar, Mipung
}

\author{
Mahn Jo Kim, Uk Lee', Kwang Ok Byun, Moon Ho Lee, \\ Myung Suk Jung, and Yong Hee Kwon
}

Department of Forest Genetic Resources, Korea Forest Research Institute, 44-3 Omokcheon-Dong, Suwon 441-847, Republic of Korea

Additional index words. Korean native chestnut, cultivar, Mipung, nut quality, yield

A new chestnut cultivar, Mipung (Castanea kusakuri Blume), was released from Korean native chestnut trees by the chestnut laboratory of the Korea Forest Research Institute (KFRI) in 2005. This cultivar was first selected from a natural population in 1984, and the preliminary, advanced, and regional yield trials for evaluation were carried out from 1985 to 2005 . 'Mipung' is a late-ripening cultivar with an optimal ripening date in late September. It has good nut quality for eating raw and processing. Average nut weight is $27.3 \mathrm{~g}$, which is much heavier than that of the control cultivar, Arima (C. crenata). It is also identified as resistant to chestnut blight disease and chestnut gall wasp. The average yield of 8 -yearold 'Mipung' was $8.8 \mathrm{~kg}$ per tree, which is superior to that of 'Arima'.

\section{Origin}

'Mipung' (Castanea kusakuri Blume) chestnut was selected in 1984 from superior and indigenous individuals located at Gyohangri, Jumunjin-eup, Gangneung-si, and Gangwondo, Republic of Korea. Since 1984, the cultivar has been vigorous and produced much heavier fruit uniformly throughout the fruiting season. Also, the cultivar has shown resistance to chestnut blight disease and chestnut gall wasp.

\section{Description and Performance}

Using the technique of veneer grafting, 'Mipung' (Castanea kusakuri Blume) was first tested for propagation in the experiment nursery in the Department of Forest Genetic Resources of the KFRI in 1984. Surviving seedlings were transplanted in the spring of 1985 in the genetic examination forest in KFRI, and the first selection was conducted from 1985 to 1998 . In 1999, the examination forest initiated the advanced and regional adaptation trails in the four experiment stations of KFRI (Suwon, Jinju, Gongju, and

Received for publication 7 Apr. 2008. Accepted for publication 10 July 2008 .

${ }^{1}$ To whom reprint requests should be addressed; e-mail rich26@forest.go.kr
Chuncheon) for examination of each individual tree's productivity and characteristics. The test site was nonirrigated and was not frost-protected, but conventional fertilizer applications were made. The cultivar Arima (C. crenata) was used as a standard for comparison. Introduced first from Japan, this cultivar has large fruit, good yields, and excellent plant vigor and has also been generally cultivated in Korea (Chung, 2006).

We evaluated the new Mipung cultivar from 1985 to 1999 for bursting time of leaf bud and leaf characteristics, flowering and fructification characteristics, harvesting time, yield and morphological nut characteristics, and nut traits on five grafted seedlings according to guidelines for the conduct of tests for distinctness, homogeneity, and stability in France chestnut (Castanea sativa Mill.) (Rural Development Administrator, 1995). For soluble solids content, we estimated the fruit juice extracted from the nuts with a refractometer (RA-510; Kyoto Electronics MFC. Co., Ltd., Kyoto, Japan) within $48 \mathrm{~h}$ after randomly selecting 10 good nuts. We examined kernel hardness for kernels without shells with a material tester (Ez-Test/CE; Shimadzu Co., Kyoto, Japan). Polyembryonic nut and pericarp splitting converted the detected nut number into a percentage. The values provided are the average of 3 years (2003 to 2005) of data collection.

For bursting time of leaf bud and leaf characteristics, 'Mipung' bursts into leaf bud around 29 Apr. and is observed to be $1 / 2$ or partially $2 / 5$ in phyllotaxis. 'Mipung' has 21.5 lateral leaf veins, a mucronate incision shape of the leaf margin, a cordate shape of the leaf blade base, a leaf length to leaf width ratio of 3.6, and a leaf length to petiole length ratio of 8.8 (Table 1). The winter bud of the cultivar is dark red in color with hairs, whereas the dormant bud is reddish brown in color with a hairless bud. The cultivar shows many bearing branches, thick and short-bearing mother branches, vigorous tree force, and a half-erect tree shape. Also, the cultivar was observed to have resistance to chestnut blight disease and chestnut gall wasp (data not shown). The staminate flowering period of 'Mipung' is from 12 June to 23

Table 1. Time of leaf bud burst and leaf characteristics of 'Mipung'.

\begin{tabular}{|c|c|c|c|c|c|c|c|}
\hline Cultivars & $\begin{array}{c}\text { Bursting } \\
\text { time of } \\
\text { leaf bud }\end{array}$ & Phyllotaxis & $\begin{array}{l}\text { No. of } \\
\text { leaf lateral } \\
\text { veins }\end{array}$ & $\begin{array}{l}\text { Incisions of } \\
\text { leaf margin }\end{array}$ & $\begin{array}{l}\text { Shape of } \\
\text { base of } \\
\text { leaf blade }\end{array}$ & $\begin{array}{c}\text { Leaf } \\
\text { length/ } \\
\text { leaf } \\
\text { width }\end{array}$ & $\begin{array}{l}\text { Leaf } \\
\text { length/ } \\
\text { petiole } \\
\text { length }\end{array}$ \\
\hline & 29 Apr. & $1 / 2,2 / 5$ & $21.5 \pm 2.19 \mathrm{a}^{\mathrm{z}}$ & Mucronate & Cordate & $3.6 \pm 0.71 \mathrm{a}^{\mathrm{z}}$ & $8.8 \pm 1.21 \mathrm{a}^{2}$ \\
\hline Arima & 1 May & $1 / 2,2 / 5$ & $20.1 \pm 2.21 \mathrm{~b}$ & Dentate & Obtuse & $4.1 \pm 0.92 b$ & $11.0 \pm 2.18 \mathrm{~b}$ \\
\hline
\end{tabular}

${ }^{2}$ Means \pm SD done by $t$ test (Duncan's multiple range test) at $P=0.05$ on five plants per cultivar $(\mathrm{n}=20)$; similar letters within a column indicate no significant difference.

Table 2. Flowering period of 'Mipung'.

\begin{tabular}{|c|c|c|c|c|c|c|c|c|}
\hline \multirow[b]{2}{*}{ Cultivars } & \multicolumn{4}{|c|}{ Staminate flower } & \multicolumn{4}{|c|}{ Pistillate flower } \\
\hline & $\begin{array}{l}\text { Flowering } \\
\text { beginning }\end{array}$ & $\begin{array}{l}\text { Full bloom } \\
\text { beginning }\end{array}$ & $\begin{array}{c}\text { Full } \\
\text { bloom } \\
\text { end }\end{array}$ & $\begin{array}{c}\text { Flowering } \\
\text { end }\end{array}$ & $\begin{array}{l}\text { Flowering } \\
\text { beginning }\end{array}$ & $\begin{array}{c}\text { Full bloom } \\
\text { beginning }\end{array}$ & $\begin{array}{c}\text { Full } \\
\text { bloom } \\
\text { end }\end{array}$ & $\begin{array}{l}\text { Flowering } \\
\text { end }\end{array}$ \\
\hline Mipung & 12 June & 16 June & 20 June & 23 June & 9 June & 13 June & 18 June & 22 June \\
\hline Arima & 10 June & 15 June & 19 June & 22 June & 9 June & 14 June & 18 June & 22 June \\
\hline
\end{tabular}
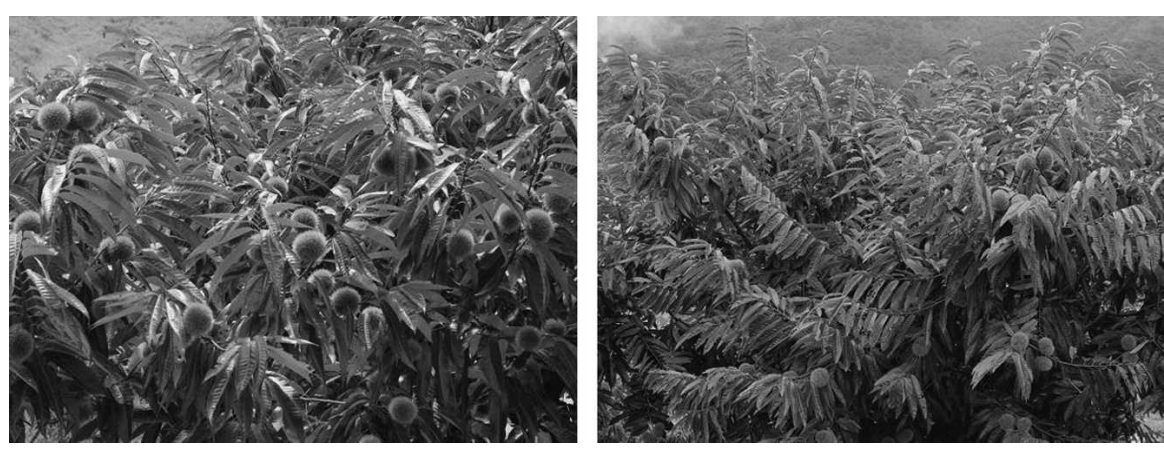

Fig. 1. Fructification of 'Arima' (left) and 'Mipung' (right) in late September. 
June with a full bloom period from 16 June to 20 June. The pistillate flowering period is from 9 June to 22 June with a full bloom period from 13 June to 18 June (Table 2). The cultivar is considered to be late-flowering when compared with the Arima cultivar, which has been generally cultivated in Korea.

The number of bearing branches per bearing mother branch and the number of burrs per bearing branch is minimal. Although the total yield was generally high because the cultivar produces a great number of fine nuts even on younger, smaller branches, the bearing mother branch is well developed and has large nuts (Fig. 1;
Table 3). Mipung is a high-yielding cultivar with an 8-year-old tree capable of producing $8.8 \mathrm{~kg}$ of nuts. This is also a late-ripening cultivar and is optimally harvested around 30 Sept. The cultivar is expected to serve as a competitive cultivar for securing labor power and chestnut markets (Table 4).

'Mipung' has short and dense burs, dark brown nuts somewhat triangular in shape, good gloss, a nut height to nut width ratio of 0.79 , and a hilum length to nut width ratio of 0.97 (Fig. 2A-B; Table 4). Hence, the variety resulted in larger nuts and a higher yield compared with the Arima cultivar. Moreover, the nuts from 'Mipung' can be more

Table 3. Flowering and fructification characteristics of 'Mipung'.

\begin{tabular}{lcccc}
\hline Cultivars & $\begin{array}{c}\text { No. of pistillate } \\
\text { flowers per } \\
\text { bearing branch }\end{array}$ & $\begin{array}{c}\text { No. of bearing } \\
\text { branch per bearing } \\
\text { mother branch }\end{array}$ & $\begin{array}{c}\text { No. of total } \\
\text { burr per bearing } \\
\text { mother branch }\end{array}$ & $\begin{array}{c}\text { No. of burr } \\
\text { per bearing } \\
\text { branch }^{\mathrm{x}}\end{array}$ \\
\hline Mipung & $1.19 \pm 0.37 \mathrm{a}^{\mathrm{z}}$ & $2.0 \pm 0.18 \mathrm{a}^{\mathrm{z}}$ & $2.4 \pm 1.10 \mathrm{a}^{\mathrm{z}}$ & $1.17 \pm 0.12 \mathrm{a}^{\mathrm{z}}$ \\
Arima & $1.76 \pm 0.57 \mathrm{~b}$ & $2.6 \pm 0.34 \mathrm{~b}$ & $4.2 \pm 0.83 \mathrm{~b}$ & $1.62 \pm 0.51 \mathrm{~b}$ \\
\hline
\end{tabular}

${ }^{\mathrm{z}}$ Means \pm SD done by $t$ test (Duncan's multiple range test) at $P=0.05$ on five plants per cultivar $(\mathrm{n}=20)$; similar letters within a column indicate no significant difference.

${ }^{\mathrm{y}}$ Measured during the third week of June.

${ }^{x}$ Measured during the third week of Sept.

Table 4. Harvesting time, yield and morphological nut characteristics of 'Mipung'.

\begin{tabular}{lcclcc}
\hline Cultivars & $\begin{array}{c}\text { Optimal } \\
\text { harvest time }\end{array}$ & Yield $^{\mathrm{z}}(\mathrm{kg} /$ tree $)$ & Nut shape & Nut ht/nut width & $\begin{array}{c}\text { Hilum } \\
\text { length/nut width }\end{array}$ \\
Mipung & 30 Sept. & $8.8 \pm 1.22 \mathrm{a}^{\mathrm{y}}$ & Broad oblate & $0.79 \pm 0.08 \mathrm{a}^{\mathrm{y}}$ & $0.97 \pm 0.11 \mathrm{a}^{\mathrm{y}}$ \\
Arima & 20 Sept. & $7.9 \pm 1.13 \mathrm{~b}$ & Oblate & $0.83 \pm 0.03 \mathrm{~b}$ & $0.97 \pm 0.20 \mathrm{a}$ \\
\hline
\end{tabular}

${ }^{\mathrm{z}}$ Measured during the fifth week of Sept. (for 'Mipung') and the fourth week of Sept. (for 'Arima'); measured 8 years old for yield.

${ }^{\mathrm{y}}$ Means \pm SD done by $t$ test (Duncan's multiple range test) at $P=0.05$ on five plants per cultivar $(\mathrm{n}=20)$; similar letters within a column indicate no significant difference.
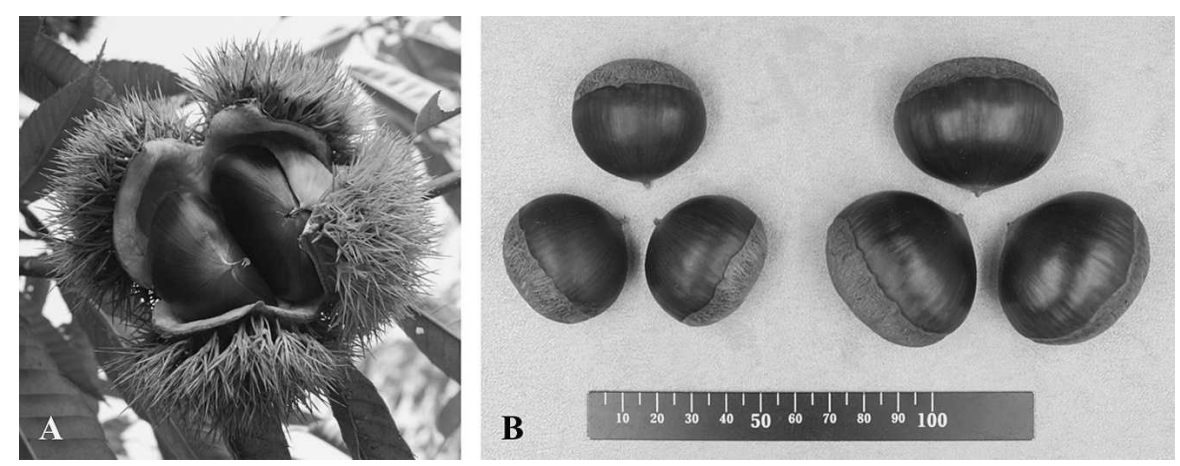

Fig. 2. (A) Opening of burr in late September. (B) Nut size and nut shape (left: 'Arima', right: 'Mipung').

Table 5. Nut traits of 'Mipung'.

\begin{tabular}{|c|c|c|c|c|c|}
\hline Cultivars & Nut $w t^{z}(g)$ & $\begin{array}{c}\text { Soluble solid } \\
\text { content }(\%)\end{array}$ & $\begin{array}{l}\text { Kernel hardness } \\
\quad\left(\mathrm{kg} \cdot \mathrm{cm}^{-2}\right)\end{array}$ & $\begin{array}{c}\text { Percent of } \\
\text { polyembryonic } \\
\text { nuts }^{z}\end{array}$ & $\begin{array}{l}\text { Percent with } \\
\text { the pericarp splitz }\end{array}$ \\
\hline$\overline{\text { Mipung }}$ & $27.3 \pm 1.15 \mathrm{a}^{\mathrm{y}}$ & $13.0 \pm 1.23 \mathrm{a}^{\mathrm{y}}$ & $9.3 \pm 1.42 \mathrm{a}^{\mathrm{y}}$ & $3.7 \pm 1.11 \mathrm{a}^{\mathrm{y}}$ & $0.5 \pm 0.06 \mathrm{a}^{\mathrm{y}}$ \\
\hline Arima & $18.1 \pm 1.32 \mathrm{~b}$ & $12.8 \pm 1.19 \mathrm{~b}$ & $8.4 \pm 1.64 \mathrm{~b}$ & $0.0 \mathrm{~b}$ & $0.1 \pm 0.03 \mathrm{~b}$ \\
\hline
\end{tabular}

similar letters within a column indicate no significant difference. 105-109. Korea Forest Research Institute, Suwon, Korea.

Kim, M.J., U. Lee, M.S. Hwang, M.H. Lee, and S.C. Kim. 2003. Nut characteristics of chestnut cultivars cultivated in Korea. Proc. of the 2003 Summer Meeting of the Korean Forest Society, p. 322-324.

Rural Development Administrator. 1995. Manual for agricultural investigation. RDA, Suwon, Korea.

On 17 July 2006, the new cultivar Mipung was granted cultivar protection by seed industry law (Korea seed and variety service, application number 09-0001-4) and is curchoring program may contact the Korea Forest Research Institute, Chestnut Research Center, 44-3 Omokcheon-dong, Suwon, Republic of Korea or rich26@forest.go.kr.

\section{Literature Cited}

easily processed as a result of their unique

Nut weight is a very large $27.3 \mathrm{~g}$ with a soluble solid content of $13.0 \%$ after harvestpolyembryonic nuts, and $0.5 \%$ pericarp splitting (Table 5). Polyembryonic nuts have because they must be excluded not only for also because they are too difficult to but and process (Kim et al., 2003). Although was not great, we predict that this nut has a great potential future product value for processing use because it is not polyembryonic

\section{Notes and Spreading Prospects in Cultivation}

'Mipung' results in good fructification and stable yield after reaching adulthood cultivation, it can difficult to achieve stable yields with biennial fructification cultivars. intensive cultivation because of the large fructification. However, the cultivar does demand proper pruning and fertilizer control; of few falling fruits after bearing pistillate flowers.

which is deep in soil depth and has proper moisture. Although the cultivar is lower in
yield than some other cultivars, it bears pistillate flowers well at an early age and has a large and uniform nut. 